\title{
Analysis of the History Learning Model Based on the Great Mosque Nur Sulaiman Banyumas in SMA Negeri Baturraden
}

\author{
Suci Rahayu*; Sariyatun Sariyatun; Leo Agung \\ Department of History Education, Universitas Sebelas Maret, Indonesia \\ Email: sucyrahayuu12@gmail.com
}

http://dx.doi.org/10.18415/ijmmu.v5i5.317

\begin{abstract}
This study describes the role of the use of learning models which applied to students through historical materials of the Great Mosque Nur Sulaiman in Banyumas toward students' learning outcomes. Using qualitative description research here,the researchers described what learning needs to be met by teacher in achieving the maximum learning process. In addition, the use of learning models which applied in the classroom, especially related to the historical material of the Great Mosque of Nur Sulaiman, it was able to be used to foster students' tolerance attitude. In the process of learning, the teacher described the history of the Great Mosque Nur Sulaiman, which in this case, it was also part of local history that exist in Banyumas. Therefore, from this description, which associated with the learning model, it gave students an understanding about the importance of local history in the process of improving students' tolerance attitude.
\end{abstract}

Keywords: Learning Model; History of Nur Sulaiman Great Mosque; Aculturation Value

\section{Introduction}

In this era, the use of varied learning models is needed by students. Teachers as academic staff should be able to optimally apply the various learning models. One of the goals of using learning model according to Muizadin \& Santoso (2016: 237) that is used to help teachers in applying the teaching materials so that they need to convey to the students. Thus, in applying the model of learning a teacher should better understand the various models of learning in accordance with student learning needs.

Today there are still history teachers who embrace the old paradigm as the only alternative. They teach by lecture method and have been framed in the material contained in the book and expect the students to sit, stay, listen, record and memorize (Pakaya., 2008: 2). In the context of learning history, the use of learning models is no longer at the lecture stage. Learning model with through lecture model, especially I, it learning history is not in accordance with the needs of students. Historical materials requires problem solving and analysis, it is more appropriate to use discussion learning models and various other models (other than variouslecture models). The success rate in learning history is in learning itself, it is able to cultivate students' ability to construct the present condition by linking or looking at past period that becomes the basis of history learning. The ability to do this construction should be strongly 
stated so that learning does not fall into conservative learning. The historical contextuality must be strongly compelling and based on the students' personal experience. Moreover, history will not be separated from the concept of time, continuity and change (Subakti., 2010: 4).

The existence of the value of Nur Sulaiman Mosque in Banyumas is not known much, especially for students. The grand mosque of Nur Sulaiman has historical value which its assessment can be used as historical tour for students. From studying the history of the mosque, students will be able to understand the collective local history that occurred in Banyumas. Local history becomes important because students must have an awareness of curiosity about the development of previous life in the past period. Consciousness is not merely curiousity but it is accompanied by an understanding of the facts of its historical events (Kusnoto \& Minandar., 2017: 130). Therefore, it takes a learning model that can deliver students to understand the history that occurred in Banyumas. To be able to solve the local history teaching management by using various learning models, then in this research, firstly, it was done by analysis which needed appropriate learning model to be used in SMA Negeri Baturraden. Local history is important because through learning it, we can know the origin, growth and setbacks of local community groups (Priyadi., 2012: 7).

\section{Methodology}

Know the result of research, hence it was used research method which directing researcher. The function of the research method is to give direction to a researcher about what things to do during the study. This study is a qualitative research, with the aim was to describe every problem found in the field. Qualitative description is used to harass the problem through analyzes.

\section{History Learning Model in SMA Negeri Baturraden}

Preliminary study which conducted through research, it was done on December 5, 2017, its purpose was to determine the model of historical learning which used in SMA Negeri Baturraden, Banyumas District. Based on the assumption of the preliminary study, it showed the need for innovative learning models. In this study, the researchers discussed one of the historical sites which located in Banyumas District, the Great Mosque Nur Sulaiman Banyumas. Historical sites could also arouse students' awareness, especially giving appreciation and understanding (Aman., 2011: 33) about the importance of studying local history (Widja., 1989: 13).

Based on the results of interviews conducted with teachers of history subjects class XI IPS (Social program) namely Mrs. Dra. Yulianti Nurasih Kadartinah (December 5, 2017), She said that:

"The Sources of local history and culture of Banyumas Regency still lacked access and also the source of local communities was very limited. Likewise the source of history and culture associated with the acculturation values of the Great Mosque Nur Sulaiman, there were still many students who did not know the local history contained in the area of Banyumas itself. Another factor that become constraint was that there were no SK (standard competence) or KD (basic competence) which discussed the history and local culture, especially in Banyumas Regency. This certainly made it difficult for students to know the history and culture of the region ".

Furthermore, the same statement submitted by Mr. Fahmi Al Assari S. Pd (December 5, 2017) about the need of a recent innovation model of history learning in SMA Negeri Baturraden. He said: 
"It has been done the application of teaching methods using learning media and learning models which supported the accordance with the rules. However, for understanding the local history and culture for students, it was still very low. It was also related to the interest of students in learning their own culture, so that with the application of a model of learning related to local historical values would greatly help learners to know the history and culture which exist in the region itself".

Based on the results of initial observation at school, found some obstacles which faced by teachers at schools, especially teachers of history subjects. The constraints faced by them in general were the attitudes of the learners during the learning process in the classroom. Based on observation from the researchers and a brief discussion with some of the learners that existed at the beginning of the preliminary study, the researchers found that the methods used by teachers of history subject were more focused on lectures, and the materials that prepared and it also focused on the existing printed book, causing the majority of learners to show indifference to the material presented. There was no learning model that utilized the culture or historical sources around the learner's environment, causing the appearance of an uninteresting impression on the subject of history. In addition to change the model of learning, teachers also have task to provide learning motivation to students (Sardiman., 2014: 76), so that they would remain diligent in learning.

Based on the results of the interview which done in the preliminary study, it could be concluded that the need for historical learning model in SMA Negeri Baturraden was very important, especially in class XI IPS. Thus, the application of the integration model of acculturation values of Nur Sulaiman Great Mosque wad expected to improve students' tolerance attitude that could be a solution to meet the material needs of historical values contained in Banyumas Regency.

\section{The Need Analysis of Teachers and Learners about the History Learning Model}

The need analysis was done through giving questions in form of questionnaire to be given to teachers and learners. There were some questions, especially which lead to the history learning that had been going on both according to teachers and learners. Based on the results of the analysis of questionnaire given to learners associated with the acculturation values of the Great Mosque Nur Sulaiman, most of the students gave a positive response to such learning model that would be developed in the history learning. According to Hamdani (2011: 24-25) before developing a learning model, a thing that must be considered was the problem faced by students in the classroom, whether or not the model was developed. Early knowledge of learners about the history and values of acculturation of Nur Sulaiman Great Mosque as one of history's work was also still minimal. Most learners knew about the Great Mosque Nur Sulaiman, but they did not know yet the cultural values existing in the Great Mosque Nur Sulaiman Banyumas. Thus, learners considered that it was necessary to take the values in the history and culture contained in the Great Mosque of Nur Sulaiman to be applied in everyday life.

Teachers also considered that the need to include the values contained in the Great Mosque of Nur Sulaiman to be an example in learning. In addition, to raise the local culture (Java community), teachers hoped that learners should understand the cultural history that currently faded, and more appreciated the ancestral culture. However, there were some limitation and difficulties in obtaining information sources, causing teachers and learners to be less interested in learning it, so there was a need for new breakthrough to make history learning more interesting and meaningful (Agung \& Wahyuni., 2013: 65). This should be done so that an effort to preserve local culture or local history by using learning model of history based on acculturation values of Nur Sulaiman Banyumas Great Mosque could be done well. 


\section{Students' Understanding about the Values of Acculturation of Nur Sulaiman Banyumas Mosque in State Senior High School of Baturraden}

This research was not only wanted to contribute a concept of learning, but the most important was the delivery of values contained in the acculturation of the Great Mosque Nur Sulaiman Banyumas, a message that contained various values of cultural blend in a mosque architecture model, it certainly described the condition of local culture in Banyumas at the time.

The plan floor of the Great Mosque of Nur Sulaiman Banyumas was square. The rectangular mosque plan was one of the hallmarks of ancient mosque buildings in Indonesia and it was a blend of Hindu-Buddhist, Indonesian and Islamic culture. This certainly illustrates the high tolerance attitude of the people of Banyumas at that time, it appreciated the difference, even combined the various types of culture in a building of worship which was considered sacred, so that from the mixing of the culture, it brought harmony.

In the architectural design of the Great Mosque of Nur Sulaiman, there were values of acculturation of Hindu-Buddhist, Indonesian, and Islamic cultures in it. This shows the values or elements of goodness contained in the mosque, such as mutual respect, acceptance of difference or tolerance, and religious attitude. Based on the values that was adapted from Masjid Agung Nur Sulaiman and it became the basis of this research, which was the acculturation values of the Great Mosque Nur Sulaiman could be applied to the learning model in order to improve students' tolerance attitude.

This study raised one of the proof of cultural heritages, the Great Mosque of Nur Sulaiman which was the oldest mosque in Banyumas Regency. The existence of Nur Sulaiman Great Mosque was a common knowledge in Banyumas, but based on the preliminary study of questionnaire need analysis, it showed that there were still many students especially in SMA Negeri Baturraden who did not understand well from the acculturation values of the Great Mosque.

Based on the analysis of need analysis conducted in XI IPS 1 and 3, the researcher got results indicating that about $60 \%$ of students who did not know the Grand Mosque of Nur Sulaiman while $40 \%$ of students knew it, but they did not understand about the acculturation values in it. It can be concluded that the students' knowledge about the Great Mosque of Nur Sulaiman Banyumas and also its acculturation values contained was still very low, whereas almost all of the students were the native people of Banyumas Regency. Therefore, the role of teachers was very important in the effort to guide and motivated them to be able to interact with the surrounding environment, and also facilitated students by organizing local sources to generate their love with local culture. Based on the previous preliminary study, there were several points that could be concluded, namely: (a) the Application of history learning model in SMA Negeri Baturraden which had been done well in accordance with the rules applicable with the curriculum both in the scope of KTSP and Curriculum 2013; (b) Students' understanding about the local history was still low, making it difficult to socialize about the local culture initially; (c) The limitation of local history and cultural resources were constrained in the availability of learning resources, so that students were required to learn about the local history and culture well; (d) The absence of a special space in the curriculum which addresses the local history and culture, making it difficult for teachers to find local materials to be applied to the learning process; (e) students' understanding about Nur Sulaiman Great Mosque was still very limited; (f) There was still a need for counseling about tolerance attitude among students.

Based on the explanation of the main problem above, it could be concluded that the condition of applying the learning model based on history and local culture for the State Senior High School of Baturraden was still low, so that it brought solution to overcome this limitation, especially about the teaching material about achitectural blend of Hindu, Buddha, Islam and Local Grand Mosque of Nur 
Sulaiman. This research aimed to integrate the acculturation values of the Great Mosque of Nur Sulaiman with respect to the students' tolerance attitude, therefore it is necessary to develop a model of learning which was able to increase students' tolerance attitude, more than that the most important goal was the change of attitude through behavior as character development so that they were able to become a person who had a high tolerance attitude.

\section{Conclusion}

Model of learning in this modern era, it seems to be a basic requirement in the world of education. Teachers as educators should be able to provide the ability to develop various models of learning. In history learning, the need of learning model is very important, especially the learning model which can be combined with the local history materials. In SMA 1 Batturaden so far it does not use a learning model in combination with local history materials yet, so that in learning process, teachers can be said that they were not able yet to create learning model through variety of local history. Therefore, it was necessary to develop a model of local history learning through linking the history of the Great Mosque of Nur Sulaiman. By studying the history of the Great Mosque Nur Sulaiman, students would be given an understanding of values contained in it.

\section{References}

Aman. (2011). Model Evaluasi Pembelajaran Sejarah. Yogyakarta: Ombak.

Agunng, Leo \& Wahyuni, Sri. (2013). Perencanaan Pembelajaran Sejarah. Yogyakarta: Ombak.

Hamdani. (2011). Strategi Belajar Mengajar. Bandung: Pustaka Setia.

Muizaddin, Reza \& Santoso, Budi. (2016). Model pembelajaran core sebagai sarana dalam meningkatan hasil belajar siswa (Core learning model for improving student learning outcomes). Dalam Jurnal Pendidikan Manajemen Perkantoran, 1(1): Halaman 235-243.

Priyadi, Sugeng. (2012). Sejarah Lokal: Konsep, Metode dan Tantangannya. Yogyakarta: Ombak.

Pakaya, Yusni. (2008). Penerapan Model Pembelajaran Kooperatif Pada Pembelajaran Sejarah. Dalam Jurnal INOVASI, 5(2). ISSN 1693-9034 1.

Sardiman. (2014). Interaksi \& Motivasi Belajar Mengajar. Jakarta: Raja Grafindo Persada.

Subakti, Y.R. (2010). Paradigma Pembelajaran Sejarah Berbasis Konstruktivisme. Dalam Jurnal SPPS, 24(1). hlm 1-23.

Yuver Kusnoto \& Fandri Minandar. (2017). Pembelajaran Sejarah Lokal: Pemahaman Kontens Bagi Mahasiswa. Dalam Jurnal Sosial Horizon: Jurnal Pendidikan Sosial, 4(1). ISSN 2407-5299.

Widja, I Gde. (1989). Sejarah Lokal Suatu Perspektif Dalam Pengajaran Sejarah. Jakarta: Departemen Pendidikan Dan Kebudayaan, Direktorat Jendral Pendidikan Tinggi, Proyek Pengembangan Lembaga Pendidikan Tenaga Kepndidikan Jakarta. 


\section{Wawancara \\ Dra. Yulianti Nurasih Kadartinah (History Teacher of Batturaden State Senior High Schoo) \\ Fahmi Al Assari S.Pd (History Teacher of Batturaden State Senior High Schoo)}

\section{Copyrights}

Copyright for this article is retained by the author(s), with first publication rights granted to the journal.

This is an open-access article distributed under the terms and conditions of the Creative Commons Attribution license (http://creativecommons.org/licenses/by/4.0/). 